\title{
Automatic Thresholding untuk Klasifikasi Perintah Arah dan Kecepatan pada Kursi Roda Elektrik dengan Menggunakan Sinyal Bioimpedansi
}

\author{
Trisa Safira Hasanah, Achmad Arifin, Muhammad Hilman Fatoni dan Siti Halimah Baki \\ Departemen Teknik Biomedik, Institut Teknologi Sepuluh Nopember (ITS) \\ e-mail: arifin@bme.its.ac.id
}

\begin{abstract}
Abstrak - Subjek yang memiliki kelumpuhan pada anggota gerak bagian atas dan bawah mengalami masalah dalam mengontrol pergerakan kursi roda. Untuk meningkatkan kemandirian subjek dengan kondisi tersebut, kami merancang metode kontrol kursi roda dengan menggunakan perubahan impedansi yang disebabkan oleh gerakan otot untuk mengontrol gerakan kursi roda. Sistem pengukuran bioimpedansi dirancang dengan menginjeksikan arus sinusoidal dengan frekuensi $50 \mathrm{kHz}$ dan arus konstan 0,5 mArms ke otot trapezius. Perubahan impedansi pada otot diukur melalui elektroda dan diinterpretasikan oleh sistem instrumentasi dan pemrosesan untuk mengendalikan gerakan kursi roda. Penelitian ini menggunakan metode automatic thresholding untuk menentukan arah dan kecepatan. Automatic thresholding digunakan karena permasalahan nilai tegangan hasil impedansi yang didapatkan terus menerus mengalami penurunan dikarenakan fatigue pada otot, sehingga nilai tegangan tidak dapat mencapai threshold. Oleh karena itu dibuatlah penggunaan automatic thresholding yang menyesuaikan dengan penurunan nilai tegangan. Pada penelitian menggunakan tiga subjek, tingkat keberhasilan yang didapatkan untuk perintah kanan dan perintah kiri mencapai $100 \%$, sedangkan untuk perintah maju, tingkat keberhasilan paling maksimum yang didapatkan adalah $80 \%$ dan paling minimum adalah $60 \%$. Selain itu, untuk perintah berhenti, tingkat keberhasilan paling maksimum yang didapatkan adalah $100 \%$ dengan tingkat keberhasilan minimumnya adalah $60 \%$.
\end{abstract}

Kata Kunci-Automatic Thresholding, Bioimpedansi, Kursi Roda.

\section{PENDAHULUAN}

$\mathrm{G}$ ANGGUAN motorik menyebabkan subjek lumpuh pada ekstremitas atas atau bawah. Salah satu solusi untuk membantu mobilitas subjek dengan gangguan motor adalah dengan menggunakan kursi roda konvensional atau listrik. Saat ini, kursi roda kebanyakan digunakan untuk membantu orang yang mengalami kelumpuhan pada ekstremitas bawah. Dalam hal ini subjek dapat mengontrol kursi roda dengan tangan. Subjek yang memiliki kelumpuhan pada bagian atas dan bawah mengalami masalah dalam mengontrol pergerakan kursi roda. Untuk meningkatkan kemandirian subjek pada kondisi tersebut, kami merancang metode kontrol kursi roda dengan menggunakan perubahan impedansi yang disebabkan oleh gerakan otot untuk mengontrol gerakan kursi roda. Penelitian mengenai kendali kursi roda elektrik dengan menggunakan sinyal bioimpedansi diteliti sebelumnya oleh Huang Yunfei menggunakan algoritma automatic threshold value adjustment dari sinyal bioimpedansi untuk pergerakan dari kursi roda [1]. Rico Ermado meneliti mengenai aplikasi bioelectrical impedance sebagai perintah kontrol gerak kursi roda elektrik menggunakan metode Proportional-Integral-derivative (PID) [2]. Juli Sardi meneliti mengenai pengembangan bioelectrical impedance sebagai perintah kontrol pengaturan kecepatan kursi roda dengan metode kontrol hirarki untuk jalanan menanjak dan menurun [3], dan Arizal Mujibtamala mengembangkan pengaturan kecepatan gerak kursi roda elektrik saat melintasi jalan menanjak dan menurun berbasis subject intention variable speed menggunakan sinyal bioimpedansi [4].

Penelitian ini menggunakan metode automatic thresholding untuk menentukan arah dan kecepatan. Automatic thresholding digunakan karena permasalahan nilai tegangan hasil impedansi yang didapatkan terus menerus mengalami penurunan dikarenakan fatigue pada otot, sehingga nilai tegangan tidak dapat mencapai threshold. Oleh karena itu dibuatlah penggunaan automatic thresholding yang menyesuaikan dengan penurunan nilai tegangan.

\section{A. Bioimpedansi}

Semua material termasuk jaringan organik didalam tubuh memiliki sifat elektrik. Bioimpedansi merujuk pada perlawanan aliran arus listrik yang melewati jaringan tubuh tersebut [5]. Dalam teknis biomedis, bioimpedansi adalah istilah yang digunakan untuk menggambarkan respons organisme hidup terhadap arus listrik dan komposisi tubuh. Besar dari impedansi didefinisikan dengan Hukum Ohm pada Persamaan (1), dimana $\bar{V}$ merupakan tegangan dan $\bar{I}$ merupakan arus. Oleh karena itu, nilai impedansi dapat

$$
\bar{Z}=\frac{\bar{V}}{\bar{I}}
$$

dihitung dengan menggunakan dua cara yaitu memberikan tegangan dan mengukur arus yang mengalir, atau memberikan arus dan mengukur tegangan keluarannya.

Elektroda merupakan transduser yang mengubah arus ionik menjadi arus elektrik. Pengukuran bioimpedansi terdiri dari pemberian arus dan pengukuran tegangan (atau sebaliknya), dan ada dua metode untuk melakukannya pada tubuh menggunakan elektroda. Metode pertama (elektroda bipolar) 

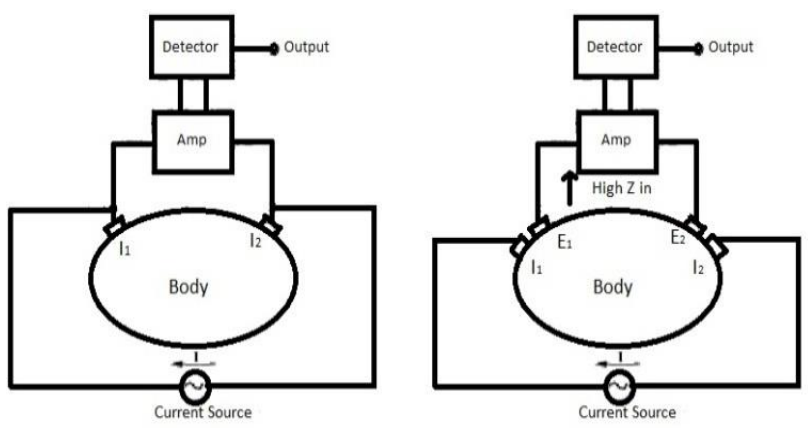

Gambar 1. Metode Pemasangan Elektroda (a) Bipolar electrode system (b) Tetrapolar electrode system

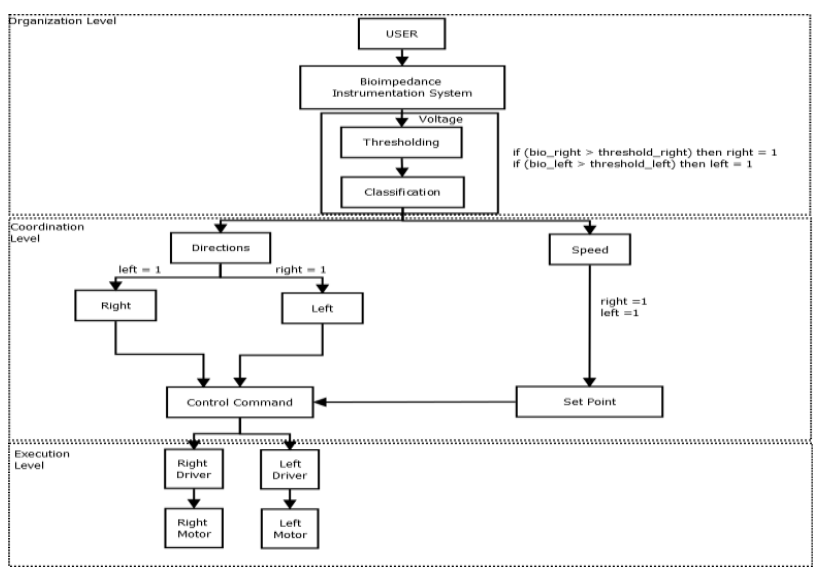

Gambar 2. Diagram Blok Sistem dengan Metode Kontrol Hirarki

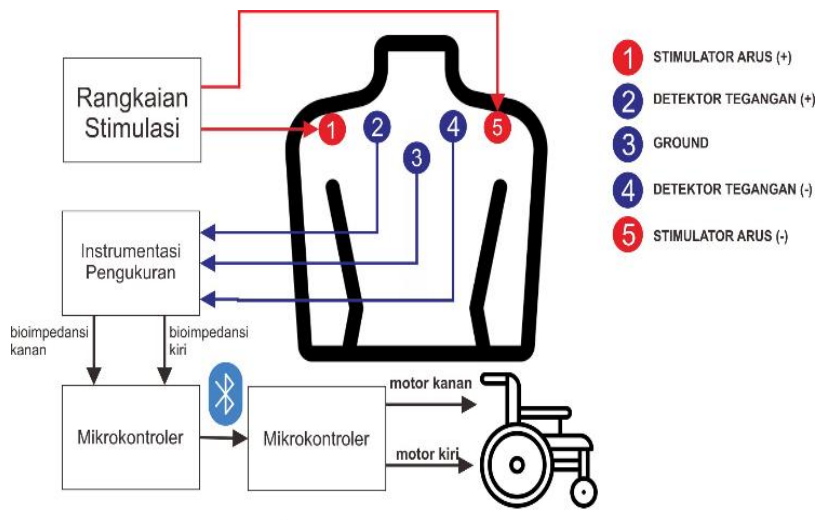

Gambar 3. Perancangan 'Sistem Bioimpedansi

menggunakan elektroda yang sama untuk menginjeksi arus dan mengukur tegangannya. Metode kedua (elektroda tetrapolar) menggunakan pasangan elektroda yang berbeda untuk menginjeksi arus dan mengukur tegangan. Metode pertama lebih mudah tetapi bukan pilihan yang bagus karena impedansi dari elektroda juga akan ditambahkan dalam pengukuran, yang akan membuat semua artefak pergerakan mempengaruhi elektroda akan mengubah hasil pengukuran [5]. Untuk metode pemasangan elektroda dapat dilihat pada Gambar 1.

Terdapat empat manfaat menggunakan bioimpedansi [6], yaitu ;(1)Frekuensi sumber arus untuk deteksi sinyal bioimpedansi dapat diatur secara manual sedangkan metode lain memiliki bandwidth yang sempit; (2)Amplitudo dari sinyal bioimpedansi lebih besar daripada sinyal electromyograph (EMG), yang membuat pengukuran menjadi lebih mudah;

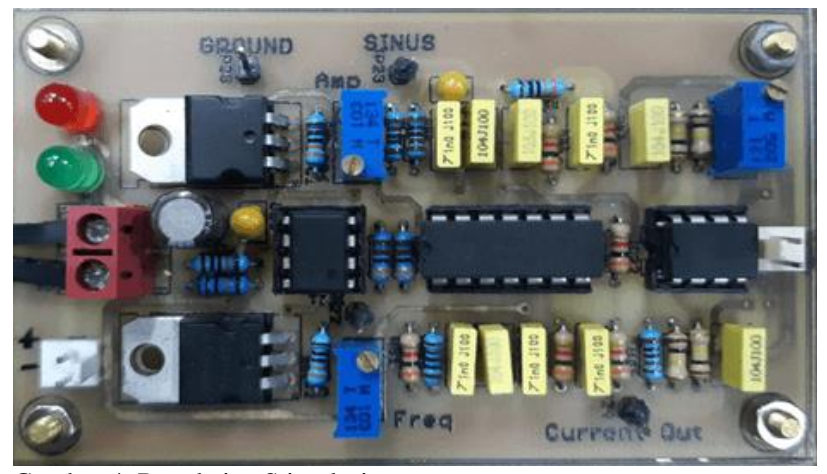

Gambar 4. Rangkaian Stimulasi

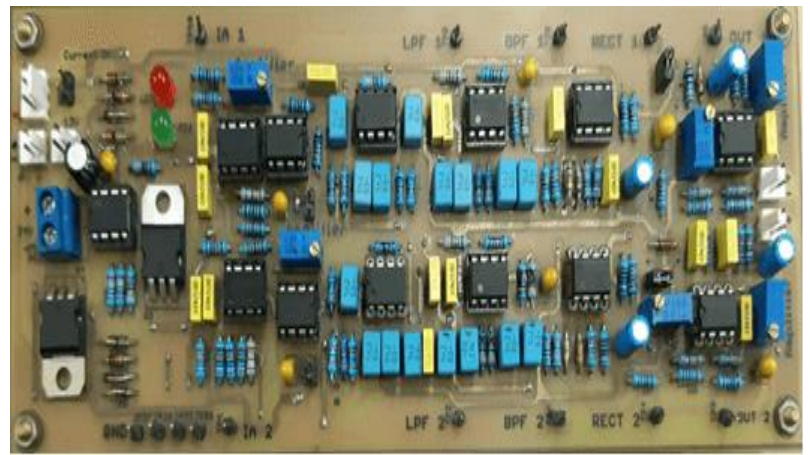

Gambar 5. Rangkaian Instrumentasi Pengukuran Bioimpedansi

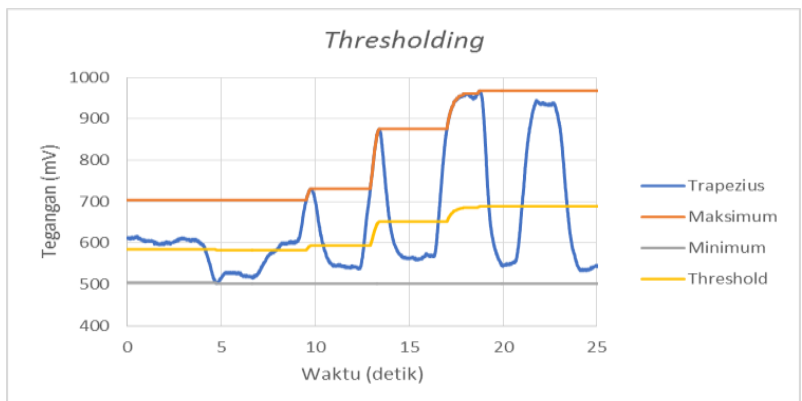

Gambar 6. Penetuan nilai threshold

(3)Karakteristik sinyal impedansi adalah sama pada setiap segmen yang diberikan untuk subjek yang sehat pada waktu istirahat dan invarian khusus, meskipun dalam waktu dan ruang yang berbeda.; (4)Karena memiliki metode non-injective, kita dapat memeriksa subjek tanpa mengalami luka atau sakit.Akan tetapi, terdapat juga kelemahan dalam menggunakan bioimpedansi yaitu sinyal bioimpedansi pada anggota badan (dada, panggul, paha, betis) dipengaruhi oleh denyut jantung, yang terjadi karena adanya cardiac output. Tetapi mereka memiliki pola yang sama. Untuk setiap segmen dan individu yang berbeda, nilai impedansi absolut juga berbeda [6].

\section{PERANCANGAN SISTEM}

\section{A. Mekanisme Gerak Kursi Roda}

Secara garis besar sistem dibagi ke dalam tiga tingkatan yaitu: tingkat organisasi, tingkat koordinasi, dan tingkat eksekusi. Tingkat organisasi berfungsi untuk mengatur dan mengendalikan gerak dari kursi roda sesuai dengan yang diinginkan. Semua jenis perintah kontrol dikeluarkan oleh 

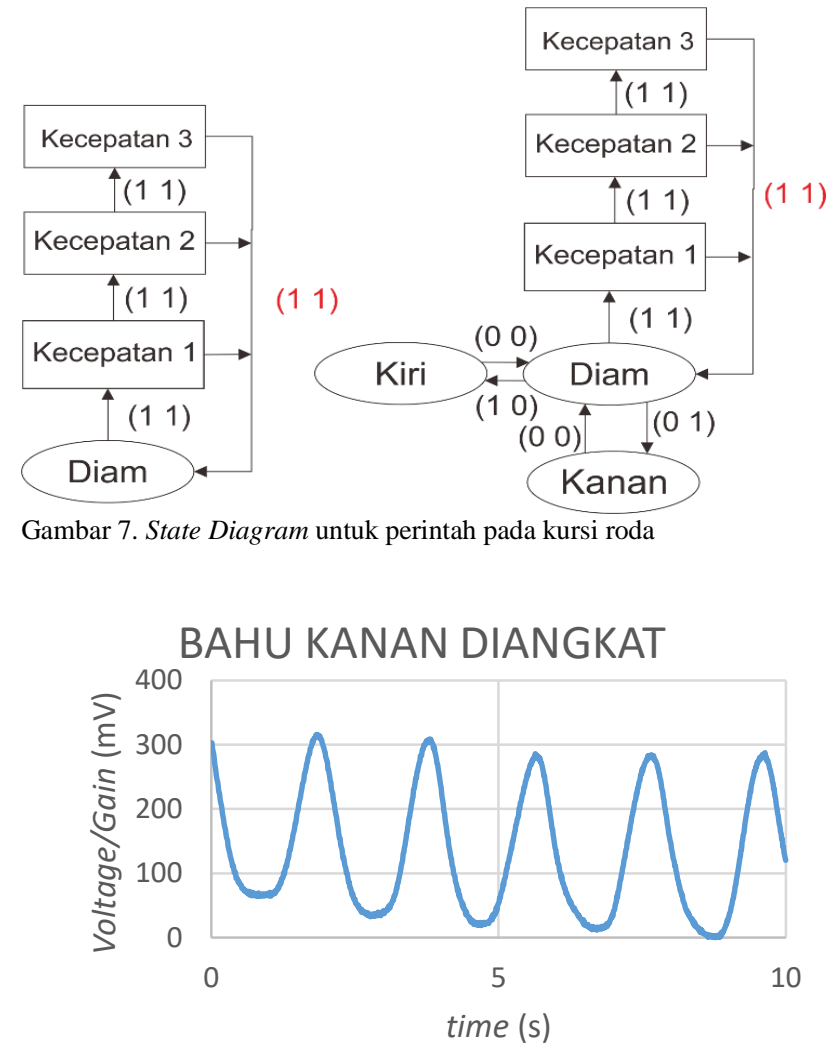

Gambar 8. Hasil dari Bioimpedansi pada Subjek A ketika bahu kanan diangkat ke atas dan ke bawah selama 10 detik

\section{BAHU KIRI DIANGKAT}

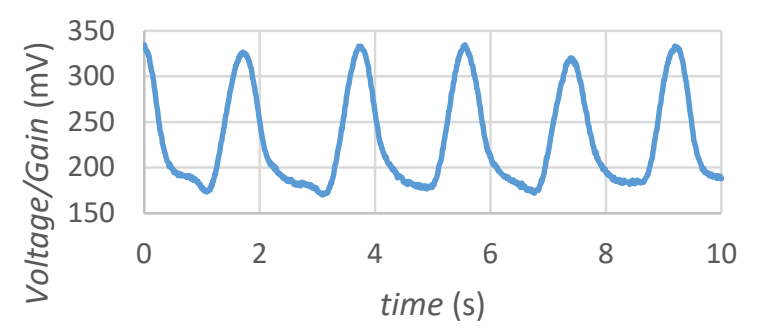

Gambar 9. Hasil dari Bioimpedansi pada Subjek A ketika bahu kiri diangkat ke atas dan ke bawah selama 10 detik

tingkatan ini. Yang termasuk dalam tingkatan organisasi ini adalah pengguna kursi roda yang memanfaatkan sinyal bioimpedansi untuk perintah kontrol gerak kursi roda. Tingkat koordinasi berfungsi mengidentifikasi perintah kontrol yang diberikan dan dijadikan sebagai set point oleh kontroler kemudian mengkoordinasikan perintah kontrol tersebut kebagian yang seharusnya. Pada tingkatan ini sinyal akan teridentifikasi dan digunakan untuk mengatur level kecepatan dari kursi roda. Tingkat eksekusi merupakan keluaran atau output yang kita inginkan yaitu berupa motor. Motor akan dijalankan agar bergerak sesuai dengan yang diinginkan. Hasil rancangan ini kemudian akan diimplementasikan pada hardware dan software. Sistem pengukuran bioimpedansi ini ditujukan untuk pengendalian gerak dari kursi roda listrik.
Tabel 1.

Perintah untuk Kursi Roda

\begin{tabular}{|c|c|c|}
\hline Perintah & Gerakan & State \\
\hline $\begin{array}{l}\text { Maju dengan } \\
\text { Kecepatan } 1\end{array}$ & 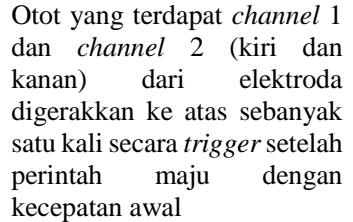 & (11) \\
\hline $\begin{array}{l}\text { Maju dengan } \\
\text { Kecepatan } 2\end{array}$ & $\begin{array}{l}\text { Setelah dilakukan maju } \\
\text { dengan kecepatan } 1 \text {, otot yang } \\
\text { terdapat di channel } 1 \text { dan } \\
\text { channel } 2 \text { (kiri dan kanan) } \\
\text { dari elektroda digerakkan ke } \\
\text { atas kembali sebanyak satu } \\
\text { kali secara trigger }\end{array}$ & $(11),(11)$ \\
\hline $\begin{array}{l}\text { Maju dengan } \\
\text { Kecepatan } 3\end{array}$ & $\begin{array}{l}\text { Setelah dilakukan maju } \\
\text { dengan kecepatan } 2 \text {, otot yang } \\
\text { terdapat di channel } 1 \text { dan } \\
\text { channel } 2 \text { (kiri dan kanan) } \\
\text { dari elektroda digerakkan ke } \\
\text { atas kembali sebanyak satu } \\
\text { kali secara trigger }\end{array}$ & $(11),(11),(11)$ \\
\hline Belok Kiri & $\begin{array}{l}\text { Otot yang terdapat channel } 1 \\
\text { (kiri) dari elektroda } \\
\text { digerakkan ke atas sebanyak } \\
\text { satu kali dan ditahan }\end{array}$ & $(10)$ \\
\hline Belok Kanan & $\begin{array}{l}\text { Otot yang terdapat } \text { channel } 2 \\
\text { (kanan) dari elektroda } \\
\text { digerakkan ke atas sebanyak } \\
\text { satu kali dan ditahan }\end{array}$ & $(01)$ \\
\hline $\begin{array}{l}\text { Berhenti dari } \\
\text { Perintah Maju }\end{array}$ & $\begin{array}{l}\text { Otot yang terdapat channel } 1 \\
\text { dan channel } 2 \text { (kiri dan } \\
\text { kanan) dari elektroda } \\
\text { digerakkan ke atas sebanyak } \\
\text { satu kali dan ditahan lama } \\
\text { hingga kursi roda berhenti }\end{array}$ & (11) \\
\hline $\begin{array}{l}\text { Berhenti dari } \\
\text { Perintah } \\
\text { Belok }\end{array}$ & $\begin{array}{l}\text { Otot yang terdapat channel } 1 \\
\text { dan channel } 2 \text { (kiri atau } \\
\text { kanan) dari elektroda tidak } \\
\text { diangkat atau diturunkan ke } \\
\text { bawah dari perintah } \\
\text { sebelumnya }\end{array}$ & $(00)$ \\
\hline
\end{tabular}

Desain perintah kontrol didasarkan pada perubahan impedansi otot pada tubuh. Impedansi otot dapat berubah ketika otot bergerak dimana nilai impedansi akan besar apabila otot memanjang dan semakin kecil apabila otot memendek. Diagram Blok dapat dilihat pada Gambar 2.

\section{B. Perancangan Hardware}

Perancangan Hardware dapat dilihat pada Gambar 3. Sistem dibagi atas 2 yaitu rangkaian stimulasi dan rangkaian instrumentasi pengukuran. Rangkaian Stimulasi digunakan untuk membangkitkan arus bolak-balik yang akan diinjeksikan pada tubuh. Rangkaian Stimulasi seperti terlihat pada Gambar 4 terdiri dari sine wave generator dan voltage current source. Rangkaian penghasil sinyal sinusoidal terdiri atas square wave generator yang berfungsi untuk menghasilkan sinyal persegi dengan tambahan adanya pengaturan frekuensi dan sinyal keluaran, low pass filter digunakan untuk mendapatkan keluaran berupa sinyal sinusoidal dari masukan sinyal persegi, dan non inverting amplifier digunakan sebagai pengatur amplitudo tegangan dari sinyal sinusiodal. Voltage Controlled 
Tabel 2.

Hasil Pengujian Subject Intention Subjek A

\begin{tabular}{ccccc}
\hline \hline Percoban & Kanan & Kiri & Maju & Berhenti \\
\hline 1 & $\sqrt{ }$ & $\sqrt{ }$ & $\sqrt{ }$ & $\sqrt{ }$ \\
2 & $\sqrt{ }$ & $\sqrt{ }$ & $\sqrt{ }$ & $\sqrt{ }$ \\
3 & $\sqrt{ }$ & $\sqrt{ }$ & $\sqrt{ }$ & $\sqrt{ }$ \\
4 & $\sqrt{ }$ & $\sqrt{ }$ & $\sqrt{ }$ & $\sqrt{ }$ \\
5 & $\sqrt{ }$ & $\sqrt{ }$ & X & $\sqrt{ }$ \\
6 & $\sqrt{ }$ & $\sqrt{ }$ & $\sqrt{ }$ & $\sqrt{ }$ \\
7 & $\sqrt{ }$ & $\sqrt{ }$ & $\sqrt{ }$ & $\sqrt{ }$ \\
8 & $\sqrt{ }$ & $\sqrt{ }$ & $\sqrt{ }$ & $\sqrt{ }$ \\
9 & $\sqrt{ }$ & $\sqrt{ }$ & X & $\sqrt{ }$ \\
10 & $\sqrt{ }$ & $\sqrt{ }$ & X & $\sqrt{ }$ \\
Akurasi & $100 \%$ & $100 \%$ & $70 \%$ & $100 \%$ \\
\hline \hline
\end{tabular}

Tabel 3.

Hasil Pengujian Subject Intention Subjek B

\begin{tabular}{ccccc}
\hline \hline Percoban & Kanan & Kiri & Maju & Berhenti \\
\hline 1 & $\sqrt{ }$ & $\sqrt{ }$ & X & $\sqrt{ }$ \\
2 & $\sqrt{ }$ & $\sqrt{ }$ & $\sqrt{ }$ & $\sqrt{ }$ \\
3 & $\sqrt{ }$ & $\sqrt{ }$ & $\sqrt{ }$ & $\sqrt{ }$ \\
4 & $\sqrt{ }$ & $\sqrt{ }$ & $\sqrt{ }$ & $\sqrt{ }$ \\
5 & $\sqrt{ }$ & $\sqrt{ }$ & X & $\sqrt{ }$ \\
6 & $\sqrt{ }$ & $\sqrt{ }$ & $\sqrt{ }$ & $\sqrt{ }$ \\
7 & $\sqrt{ }$ & $\sqrt{ }$ & $\sqrt{ }$ & $\sqrt{ }$ \\
8 & $\sqrt{ }$ & $\sqrt{ }$ & X & $\sqrt{ }$ \\
9 & $\sqrt{ }$ & $\sqrt{ }$ & $\sqrt{ }$ & $\sqrt{ }$ \\
10 & $\sqrt{ }$ & $\sqrt{ }$ & X & $\sqrt{ }$ \\
Akurasi & $100 \%$ & $100 \%$ & $60 \%$ & $100 \%$ \\
\hline \hline
\end{tabular}

Tabel 4.

Hasil Pengujian Subject Intention Subjek C

\begin{tabular}{ccccc}
\hline \hline Percoban & Kanan & Kiri & Maju & Berhenti \\
\hline 1 & $\sqrt{ }$ & $\sqrt{ }$ & $\sqrt{ }$ & $\sqrt{ }$ \\
2 & $\sqrt{ }$ & $\sqrt{ }$ & $\sqrt{ }$ & $\sqrt{ }$ \\
3 & $\sqrt{ }$ & $\sqrt{ }$ & X & X \\
4 & $\sqrt{ }$ & $\sqrt{ }$ & $X$ & $X$ \\
5 & $\sqrt{ }$ & $\sqrt{ }$ & $\sqrt{ }$ & $\sqrt{ }$ \\
6 & $\sqrt{ }$ & $\sqrt{ }$ & $\sqrt{ }$ & $\sqrt{ }$ \\
7 & $\sqrt{ }$ & $\sqrt{ }$ & $\sqrt{ }$ & $\sqrt{ }$ \\
8 & $\sqrt{ }$ & $\sqrt{ }$ & $\sqrt{ }$ & $X$ \\
9 & $\sqrt{ }$ & $\sqrt{ }$ & $\sqrt{ }$ & $\sqrt{ }$ \\
10 & $\sqrt{ }$ & $\sqrt{ }$ & $\sqrt{ }$ & X \\
Akurasi & $100 \%$ & $100 \%$ & $80 \%$ & $60 \%$ \\
\hline \hline
\end{tabular}

Current Source (VCSS) digunakan untuk mengubah sinyal tegangan sinusoidal menjadi sinyal arus sinusoidal yang nantinya akan diinjeksikan ke tubuh pengguna melalui elektroda. Rangkaian instrumentasi pengukuran seperti terlihat pada Gambar 5 digunakan untuk mendeteksi besar tegangan diantara dua titik pada bagian tubuh. Besar tegangan yang terukur merupakan besar bioimpendansinya. Besar bioimpedansi dapat diketahui dengan memanfaatkan Hukum $\mathrm{Ohm}$, yaitu dengan membagi tegangan terukur dengan besar arus yang distimulasikan. Rangkaian ini terdiri atas instrumentation amplifier, band pass filter, AC to DC Converter, dan rangkaian differential amplifier. Instrumentation Amplifier berfungsi untuk menguatkan tegangan hasil pembacaan dari hasil deteksi tegangan. Rangkaian band pass filter berguna untuk menghilangkan noise seperti sinyal dari gelombang radio dan interferensi dari sinyal tubuh lain seperti electrocardiograph (ECG), electroencephalograph (EEG), dan electromyography (EMG). $A C$ to DC Converter berfungsi untuk mengubah sinyal input AC menjadi tegangan output DC.

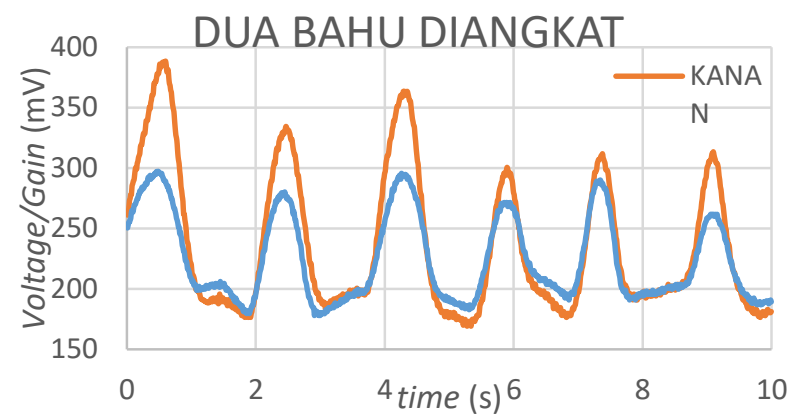

Gambar 10. Hasil dari Bioimpedansi pada Subjek A ketika bahu kiri diangkat ke atas dan ke bawah selama 10 detik

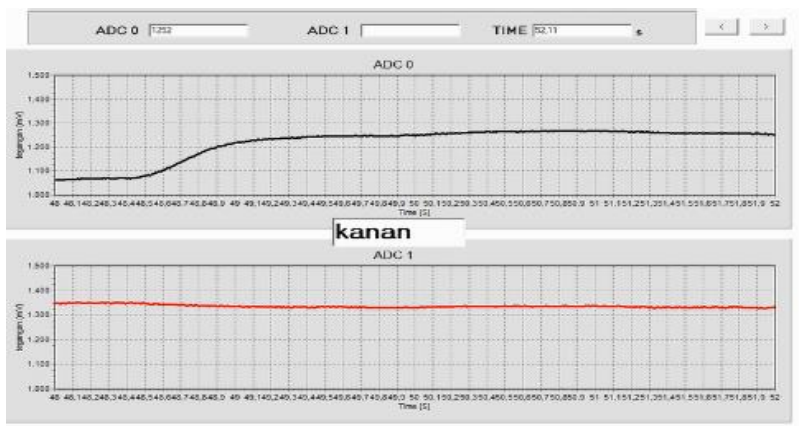

Gambar 11. Nilai tegangan ketika bahu kiri diangkat

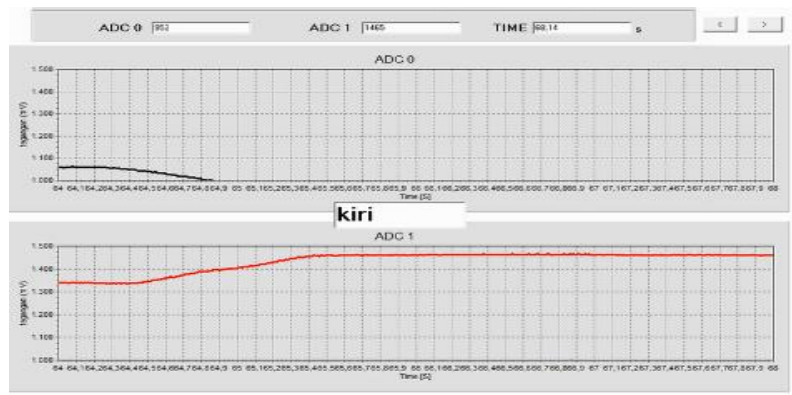

Gambar 12. Nilai tegangan ketika bahu kanan diangkat

\section{Perancangan Sistem Microcontroller}

Pada sistem pengukuran bioimpedansi, rangkaian microcontroller berfungsi dalam mengolah tegangan hasil keluaran dari rangkaian detektor tegangan bioimpedansi menjadi data digital. Hal tersebut bisa direalisasikan dengan memanfaatkan kemampuan Analog to Digital Converter (ADC) internal yang dimiliki microcontroller. Input tegangan analog berasal dari rangkaian instrumentasi bioimpedansi dan sensor kecepatan (rotary encoder). Kedua data tersebut merupakan parameter yang akan digunakan pada proses pengaturan kecepatan motor. Pada penelitian ini, digunakan 2 jenis microcontroller berupa STM32 yang dihubungkan dengan menggunakan Bluetooth dengan pin USART pada masingmasingnya sebagai slave dan master. Sistem Bioimpedansi dihubungkan dengan microcontroller yang terhubung dengan bluetooth yang berperan sebagai master yang akan mengirimkan data berupa karakter hasil thresholding ke microcontroller yang terhubung dengan Bluetooth yang berperan sebagai slave yang ada pada kursi roda. 


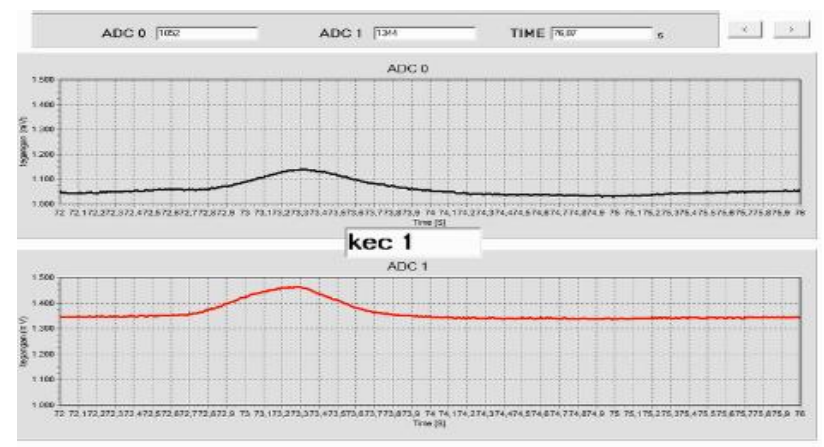

Gambar 13. Nilai tegangan ketika maju dengan kecepatan 1

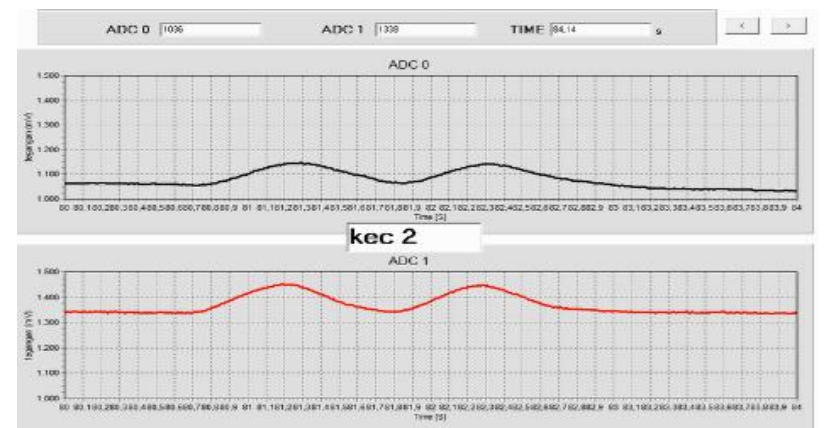

Gambar 14. Nilai tegangan ketika maju dengan kecepatan 2

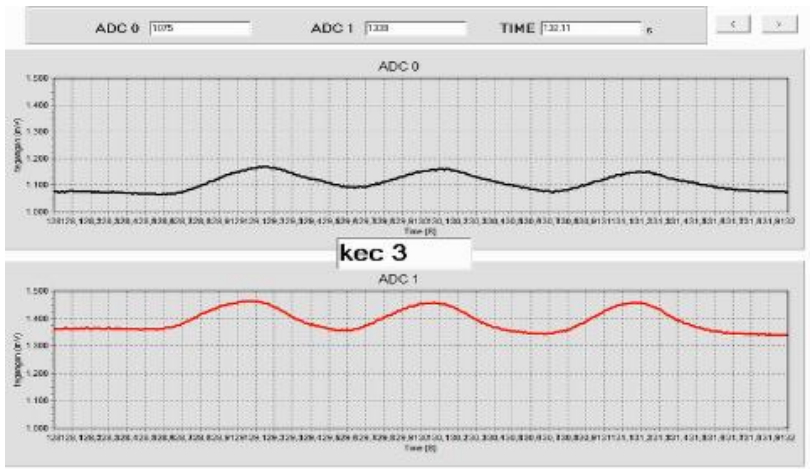

Gambar 15. Nilai tegangan ketika maju dengan kecepatan 3

\section{Automatic Thersholding untuk Klarifikasi Perintah Kontrol Kursi Roda}

Ketika otot memanjang dan nilai impedansi meningkat, maka tegangan yang terukur pada instrumentasi bioelectrical impedance akan meningkat. Apabila nilai tegangan yang terukur lebih besar daripada threshold, maka gerakan otot akan diartikan sebagai perintah kontrol dengan menggunakan deteksi tepi. Threshold merupakan cara untuk menerjemahkan perubahan impedansi sebagai perintah kontrol gerak sehingga dapat dibaca oleh microcontroller. Berhubung bioimpedansi dari otot bahu kanan dan otot bahu kiri berbeda, otot bahu kanan bisa saja lebih besar dari otot bahu kiri ataupun sebalikanya, maka threshold yang digunakan juga berbeda. Selain itu, otot yang terus-menerus distimulasi akan mengalami kondisi fatigue dimana dapat mempengaruhi nilai impedansi sehingga menurunkan nilai dari tegangan. Penurunan dari nilai tegangan akan mempengaruhi perintah kontrol karena nilai dari tegangan tidak mencapai threshold. Oleh karena itu, digunakan automatic thresholding agar didapatkan nilai threshold yang menyesuaikan dengan penurunan tegangan. Penentuan nilai threshold dilakukan dengan cara menyimpan nilai minimum dan maksimum dari hasil pembacaan sinyal tegangan yang didapatkan dari impedansi. Nilai maksimum dicari untuk melihat tegangan maksimum yang dapat dilakukan oleh otot dan nilai minimum dicari dikarenakan baseline dari sinyal yang tidak selalu pada tegangan $0 \mathrm{~V}$. Nilai total tegangan yang akan dibaca didapatkan dengan cara mengurangkan nilai maksimum dan minimumnya yang mana kemudian akan diambil $40 \%$ dari nilai tersebut untuk dijadikan threshold dan menambahkan hasil persen tersebut ke nilai minimumnya. Penentuan nilai threshold dapat dilihat pada Gambar 6.

Perangkat lunak sistem kursi roda elektrik didesain sesuai dengan mekanisme gerak yang diusulkan, dimana terdapat threshold untuk menerjemahkan perubahan impedansi pada otot trapezius sebagai perintah kontrol dan kursi roda dapat bergerak belok kanan, belok kiri, maju dengan kecepatan 1, kecepatan 2, kecepatan 3 dan berhenti sesuai dengan state diagram yang dibuat pada Gambar 7 dengan penjelasannya berada pada Tabel 1. Klasifikasi yang dilakukan berdasarkan logic perintah kontrol hasil dari proses thresholding, dimana terdapat logic 1 ketika keluaran dari bioelectrical impedance lebih dari threshold dan logic 0 ketika keluaran dari bioelectrical impedance kurang dari threshold.

Pada saat jalan mendatar, perintah yang dapat diberikan kepada kursi roda berupa perintah kecepatan dan perintah arah berupa maju, belok kanan, belok kiri, dan berhenti. Sedangkan pada saat jalan menanjak, perintah yang dapat diberikan kepada kursi roda hanya berupa perintah kecepatan. Sebagai catatan, pada saat kursi melakukan pembelokan, maka kecepatan akan dikurangi, sedangkan saat melakukan pendakian, maka kecepatan kursi roda akan dipercepat.

\section{HASIL DAN PEMBAHASAN}

\section{A. Hasil Keseluruhan Sistem Bioimpedansi}

Hasil Keseluruhan dari Sistem Bioimpedansi dilakukan dengan melihat tegangan keluaran yang didapatkan berdasarkan arus sinusoidal dengan frekuensi $50 \mathrm{kHz}$ dan arus konstan sebesar $0.5 \mathrm{~mA}$ yang diinjeksikan kedalam tubuh tepatnya pada bagian otot trapezius dan kemudian melihat perubahan tegangan akibat dari impedansi ketika otot trapezius tepatnya bagian bahu digerakkan ke atas dan ke bawah. Menurut teori, impedansi otot dapat berubah ketika otot bergerak dimana nilai impedansi akan besar apabila otot memanjang dan semakin kecil apabila otot memendek.

Subjek A berjenis kelamin perempuan berusia 21 tahun dan berat badan $54 \mathrm{~kg}$. Hasil yang ditunjukkan pada Gambar 8 menunjukkan bahwa terdapat perubahan impedansi ketika bahu kanan dari subjek diangkat ke atas dan ke bawah selama 10 detik. Tegangan berkisar pada rentang $0 \mathrm{mV}$ hingga $310 \mathrm{mV}$, sehingga dapat disimpulkan perubahan impedansi yang terjadi berkisar $310 \mathrm{mV}$. Hasil dari bioimpedansi ketika bahu kiri dari subjek diangkat ke atas dan ke bawah selama 10 detik dapat dilihat pada Gambar 9. Hasil dari pengangkatan dari bahu kiri menunjukkan bahwa terjadi perubahan impedansi dimana tegangan yang didapatkan berkisar $170 \mathrm{mV}$ hingga $335 \mathrm{mV}$, 
sehingga dapat disimpulkan perubahan impedansi yang terjadi berkisar $165 \mathrm{mV}$. Tegangan hasil bioimpedansi dari bahu kanan ketika diangkat lebih besar daripada bahu kiri dapat terjadi karena penempatan elektroda yang tidak sesuai.

Hasil bioimpedansi ketika bahu kanan dan bahu kiri diangkat secara serentak dapat dilihat pada Gambar 10. Hasil dari pengangkatan dari bahu kiri dan bahu kanan menunjukkan bahwa terjadi perubahan impedansi dimana tegangan yang didapatkan untuk bahu kanan berkisar $180 \mathrm{mV}$ hingga $390 \mathrm{mV}$ sedangkan untuk bahu kiri berkisar $180 \mathrm{mV}$ hingga $300 \mathrm{mV}$. Dapat disimpulkan ketika kedua bahu diangkat, maka perubahan tegangan yang ada pada bahu kanan berkisar 210 $\mathrm{mV}$ dan untuk bahu kiri berkisar $120 \mathrm{mV}$. Perubahan tegangan pada kedua bahu mengalami penurunan dikarenakan kedua bahu saling berhubungan dan mempengaruhi perubahan impedansi satu sama lainnya.

\section{B. Hasil Pengujian Subject Intention}

Perangkat lunak sistem kursi roda elektrik di desain sesuai dengan mekanisme gerak yang diusulkan, dimana terdapat threshold untuk menerjemahkan perubahan impedansi pada otot trapezius sebagai perintah kontrol dan kursi roda dapat bergerak belok kanan, belok kiri, maju dengan kecepatan 1, kecepatan 2, kecepatan 3 dan berhenti. Klasifikasi yang dilakukan berdasarkan logic perintah kontrol hasil dari proses thresholding, dimana terdapat logic 1 ketika keluaran dari bioelectrical impedance lebih dari threshold dan logic 0 ketika keluaran dari bioelectrical impedance kurang dari threshold. Gambar 11, Gambar 12, Gambar 13, Gambar 14, dan Gambar 15 menunjukkan tegangan hasil dari bioimpedansi dari masing masing perintah untuk kursi roda.

Tabel 2, Tabel 3, dan Tabel 4 menunjukkan hasil pengujian subject intention pada Subjek A, Subjek B, dan Subjek C. Subjek A memiliki tingkat keberhasilan sebesar 100\% untuk perintah kanan, kiri, dan berhenti, sedangkan untuk perintah maju memiliki tingkat keberhasilan sebesar 70\%. Subjek B memiliki tingkat keberhasilan sebesar $100 \%$ untuk perintah kanan, kiri, dan berhenti yang sama dengan Subjek A, sedangkan untuk perintah maju memiliki tingkat keberhasilan sebesar 76\%. Berbeda dengan Subjek A dan Subjek B, Subjek $\mathrm{C}$ memiliki tingkat keberhasilan sebesar $100 \%$ hanya untuk perintah kanan dan kiri, tetapi untuk berhenti memiliki tingkat keberhasilan $60 \%$ sedangkan untuk perintah maju memiliki tingkat keberhasilan sebesar 80\%. Rendahnya tingkat keberhasilan dari Subjek dikarenakan penempatan elektroda yang salah akan menyebabkan kecilnya nilai tegangan yang dibaca sehingga threshold yang didapat dari penentuan persentase dari pengurangan nilai maksimum terhadap minimum dari sinyal bioimpedansi juga akan semakin mengecil yang menyebabkan sistem menjadi sangat sensitif. Subjek C memiliki kasus lain dikarenakan bentuk punggung yang mana memiliki tulang yang lebih menonjol dibanding Subjek A dan Subjek B pada tulang di otot trapezius sehingga menyebabkan elektroda yang kurang menempel. Hal ini dapat diketahui dikarenakan ketika elektroda dieratkan kembali ataupun diganti, hasil kembali menjadi normal.

\section{KESIMPULAN}

Pada penelitian menggunakan tiga subjek, tingkat keberhasilan yang didapatkan untuk perintah kanan dan perintah kiri mencapai $100 \%$, sedangkan untuk perintah maju, tingkat keberhasilan paling maksimum yang didapatkan adalah $80 \%$ dan paling minimum adalah 60\%. Selain itu, untuk perintah berhenti, tingkat keberhasilan paling maksimum yang didapatkan adalah $100 \%$ dengan tingkat keberhasilan minimumnya adalah $60 \%$. Rendahnya tingkat keberhasilan dari Subjek dikarenakan penempatan elektroda yang salah akan menyebabkan kecilnya nilai tegangan yang dibaca sehingga threshold yang didapat dari penentuan persentase dari pengurangan nilai maksimum terhadap minimum dari sinyal bioimpedansi juga akan semakin mengecil yang menyebabkan sistem menjadi sangat sensitif.

\section{DAFTAR PUSTAKA}

[1] H. Yunfei, P. Phukpattaranont, and B. Wongkittisuksa, "Wheelchair Control Based on Bioimpedance," Int. J. Appl. Biomed. Eng., vol. 3, no. 2, pp. 13-15, 2010.

[2] R. Ermado, "Aplikasi Bioelectrical Impedance Sebagai Perintah Kontrol Gerakan Pada Kursi Roda Elektrik,” ITS Digital Repository, 2012.

[3] J. Sardi, "Pengembangan Bioelectrical Impedance Sebagai Control Commands Pengaturan Kecepatan Gerak Kursi Roda dengan Metoda Kontrol Hirarki," Institut Tekonologi Sepuluh Nopember Surabaya, 2013.

[4] A. M. N. Imron, "Pengaturan Kecepatan Gerak Kursi Roda Elektrik Saat Melintasi Jalan Menanjak dan Menurun Berbasis Subject Intention Variable Speed Menggunakan Sinyal Bioelectrical Impedance," Institut Teknologi Sepuluh Nopember, Surabaya, 2016.

[5] J. Gracia Tabuenca, "Multichannel Bioimpedance Measurement," Universitat Politècnica de Catalunya, 2009.

[6] H. Yunfei, "Development of A Bioimpedance Based Human Machine Interface," Asp. Gen. La Planif. Tribut. En Venez., no. 75, pp. 31-47, 2009. 